JIM UPB

Jurnal Program Studi Manajemen

Universitas Putera Batam Vol.9 No.1

\title{
EFFECT OF DISTRIBUTION CHANNEL TO SALES VOLUME IN PT HONDA POWER PRODUCT INDONESIA
}

\author{
By \\ Faisal Rahman ${ }^{1}$, Resista Vikaliana ${ }^{2}$ \\ Logistics Management Study Program, Faculty of Management, \\ Institute of Social Sciences and Management Stiami \\ Email:dosenresistaok@gmail.com
}

\begin{abstract}
This research was conducted at PT. Honda Power Products Indonesia, with the aim to determine the effect of distribution channels on sales volume at PT. Honda Power Products Indonesia. This research approach is a quantitative approach with correlational research type. Data were collected by distributing questionnaires to 80 samples. From the calculation and data analysis, the linear regression equation is $Y=13.134+0.195 X 1+e$. The correlation coefficient obtained is 0.694, which means that the Distribution Channel variable has a strong influence on the Sales Volume variable. While the coefficient of determination obtained is 0.489, or 48.9\%. This shows that the distribution channel has an influence of $48.9 \%$ on volume, while the remaining $51.1 \%$ is influenced by other variables not included in the model or not examined by the author. The results of the $t$ hypothesis test show that the Distribution Channel variable has a positive and significant effect on the Sales Volume variable.
\end{abstract}

Keywords: Distribution channel, sales volume, linear regression

\section{INTRODUCTION}

The growing demand by consumers for better service quality and diversity in demand, coupled with increased market competition, makes companies have to think quickly and accurately, in reorganizing their business. The tight business competition from competitors of PT Honda Power products Indonesia such as Yamaha, Yanmar, and several products from China at competitive prices made PT Honda Power Products Indonesia have to think hard to streamline all its costs, so that the price given customers can compete in the market without having to reduce product quality and service quality. Therefore, in this case the selection of the right distribution channel will be useful in achieving the expected sales targets.

PT. Honda Power Product Indonesia is a subsidiary company of Honda Motor Co., Ltd, Japan, established in June 2006. PT Honda Power Products Indonesia is located at Jalan Rawa Gelam IV No.14, Pulogadung industrial area, East Jakarta. is a trading and manufacturing company engaged in the sale of multi-purpose machines, generators and fishing / marine boat engines, where the users are individuals, farmers and fishermen. The current trade war has had an impact on the world, as well as on sales at PT Honda Power Products Indonesia. So that companies are required to be able to streamline the costs incurred.

Indonesia as an archipelago country which is also one of the countries with high logistics costs, is one of the biggest challenges for PT Honda Power Products Indonesia to maximize profits. As a company that does business with sales through dealers, PT Honda Power Products Indonesia sets a standard on this minimum order quantity in order to minimize shipping costs, but when faced with weak sales, while requests / purchases from dealers do not reach the minimum order number. 
Sales volume is the total amount generated from the sale of goods. The greater the number of sales the company generates, the greater the profit the company will generate. Sales volume is the number of sales the company has successfully made. Sales volume measurement is usually shown in the form of numbers on products that have been sold to buyers. The following Table 1 shows the Sales Report of PT Honda Power Product Indonesia from April 2016 to March 2019.

Table 1. Sales report (in unit) of PT Honda Power Products Indonesia

\begin{tabular}{|c|c|c|c|}
\hline \multicolumn{4}{|l|}{ PERIOD } \\
\hline Category & $\begin{array}{l}\text { Apr- } \\
18\end{array}$ & $\begin{array}{l}\text { Apr- } \\
17\end{array}$ & $\begin{array}{l}\text { Apr- } \\
16\end{array}$ \\
\hline Engine & 166.022 & 157.228 & 158.296 \\
\hline Pump & 29.738 & 33.483 & 40.504 \\
\hline Generator & 4.276 & 4.066 & 7.941 \\
\hline Brush Cutter & 3.527 & 4.053 & 4.279 \\
\hline Outboard & 829 & 717 & 886 \\
\hline Mower & 120 & 133 & 139 \\
\hline Tiller & 1.382 & 3.432 & 4.148 \\
\hline Sprayer & 88 & 156 & 0 \\
\hline Riding Mower & 0 & 3 & 1 \\
\hline Total sales & 205.982 & 203.271 & 216.194 \\
\hline
\end{tabular}

Source: Internal of PT Honda Power Products Indonesia, 2020

Table 1 shows a decrease in total sales in the 2017-2018 period, then began to climb in the 2018-2019 period. Meanwhile, sales per category are volatile.Making standard minimum orders is often neglected so that only sales figures are pursued. A profitable sales volume should be the company's goal (Swastha, 2009). This is a big challenge for PT Honda Power Products Indonesia, namely how to minimize distribution costs without losing a sales opportunity. Distribution channel is the transfer of goods and services from producers to consumers. Distribution channel members carry out several main functions, namely helping to complete transactions and complete transactions "(P Kotler \& Keller, 2012).

In the distribution process, apart from the duties and responsibilities (Abdul et al., 2018), it also concerns customer satisfaction as an important goal when running a business (Lucyantoro \& Rachmansyah, 2017; Widjoyo et al., 2014). A good service to consumers is one of the important principles that companies must do, because if consumers are satisfied, consumers will come back to do repeat orders and even recommend the products they have bought to other people which of course will increase sales volume in the long run, according to the opinion that a creative promotion strategy is integrated marketing communication (Rangkuti, 2009a).

Consumer satisfaction is determined by the quality of service and product quality provided (Tjiptono, 2005). On the other hand, companies must also be careful and wise in carrying out their business strategies so that there are no losses due to high shipping and logistics costs (Sutapa, 2009), therefore PT Honda Power Products Indonesia through the logistics department is required to be more dynamic in following business developments and follow market demand without overriding company targets. So that it can minimize distribution costs and overall logistics costs. Therefore, the logistics department makes a strategy on the distribution channel, namely, through a systematic minimum order or selection of transportation facilities which follows the size / cubication of the vehicles and 
goods to be sent, as well as flexibility in point of delivery locations without having to follow minimum order standards.

From the background that has been described, this study aims to determine the effect of distribution channels on sales volume, in addition to knowing the magnitude of the influence of distribution channels on sales volume.

\section{METHODS}

Based on the problems in this study, this study suspects that there is an effect of distribution channels on sales volume. This is based on previous research, which proves that there is an effect of distribution channels on sales volume (Djaharuddin, 2017; Eldine, 2012; Sattar, 2016; Setianingsih et al., 2019). The independent variable in this study - Distribution Channel (X), refers to the theory with dimensions of market considerations, goods considerations, company considerations and intermediary considerations (Dhipayana, 2018). While the dependent variable - Sales Volume (Y) is based on the dimensions of selling price, product, promotional costs, distribution channels, and quality (Philip Kotler \& Keller, n.d.). The theoretical framework of this research is shown in Figure 1 below.

\begin{tabular}{|c|c|}
\hline $\begin{array}{l}\text { Distribution channel }(\mathrm{X}) \text { : } \\
\begin{aligned} & \text { 1. } \text { Market consideration } \\
& \text { 2. } \text { Goods consideration } \\
& \text { 3. Company consideration } \\
& \text { 4. Medium consideration }\end{aligned} \\
\text { Source: Dhipayana (2018) }\end{array}$ & 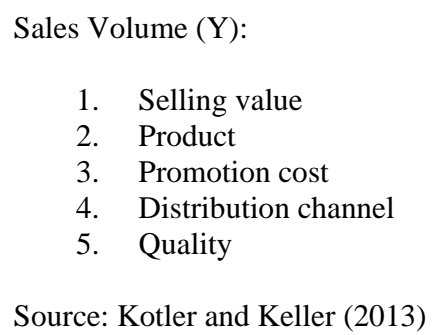 \\
\hline
\end{tabular}

\section{Picture 1. Research Theory Framework}

Based on the literature review, this research hypothesis was developed as follows: H0: There is no partial influence between X (Distribution Channel) on Y (Sales Volume) H1: There is a partial influence between X (Distribution Channel) on Y (Volume Sales)

This research uses a quantitative approach with correlational research. The variables in this study consist of Distribution Channel independent variables and the dependent variable is Sales Volume. The data collection technique was done by using a questionnaire on 80 samples. The data analysis techniques used in this study are as follows.

1. Data Quality Test (Validity Test, Reliability Test, Normality Test)

2. Classical Assumption Test (Normality Test, Heteroscedasticity Test, Multicollinearity Test, and Linearity Test)

3. Correlation analysis and determination coefficient test

4. Multiple Linear Regression Analysis,

5. Hypothesis Testing, Partial Test, $t$ test is used to test the significance of the relationship between variable $\mathrm{X}$ and variable $\mathrm{Y}$, whether the variable $\mathrm{X}$ (Distribution Channel) really affects the variable Y (Sales Volume). Data analysis was assisted by using SPSS version 23 according to the formulation or identification under study (Vikaliana \& Irwansyah, 2019) 


\section{RESULT AND DISCUSSION \\ Result}

Research conducted at PT. Honda Power Products Indonesia with the number of respondents 80 respondents showed the results that all variables were declared valid because the distribution channel variable had a calculated $\mathrm{r}$ value above 0.221 and all variables were also declared realistic because the Cronbach Alpha value was more than 0.600. All variables also follow the normal data distribution because the calculated $\alpha$ significance value of all variables is more than 0.050 , in this study there is also no heteroscedasticity problem in the regression model.

Based on the research results, each variable has a significant effect. For the distribution channel significance test of $0.047<0.05$ or the results of the $t$ test with tcount 2.017> from $t$ table of 1.992. For the Y equation from this study, it can be seen that the Understandarized Coefficient B column. The results of data processing using SPSS 23, show that: $Y=13,134+$ $0.195 \mathrm{X} 1+\mathrm{e}$, this equation shows that the volume of sales if it is not influenced by distribution channels is 13,134 units. The regression equation also shows if the distribution channel and if the distribution channel is increased by one unit, it will increase the sales volume by 0.195 or $19.5 \%$ in the distribution channel.

In this study, the hypothesis was tested, namely the $t$ test. If the probability value of significance is less than $0.050(5 \%)$, then the independent variable has a significant effect on the dependent variable. The $t$ test results can be seen from the results of data processing in Table 2.

Table 2. Coefficient ${ }^{a}$ (Result of Linear Regression and Hypothesis Test t)

\begin{tabular}{|c|c|c|c|c|c|c|}
\hline \multicolumn{2}{|c|}{ Model } & \multicolumn{2}{|c|}{$\begin{array}{c}\text { Unstandardized } \\
\text { Coefficients }\end{array}$} & $\begin{array}{c}\text { Standardized } \\
\text { Coefficients }\end{array}$ & \multirow{2}{*}{ T } & \multirow{2}{*}{ Sig. } \\
\cline { 2 - 6 } \multicolumn{2}{c|}{} & B & $\begin{array}{c}\text { Std. } \\
\text { Error }\end{array}$ & Beta & & \\
\hline \multirow{3}{*}{1} & (Constant) & 13,465 & 3,285 & & 4,099 &, 000 \\
\cline { 2 - 6 } & $\begin{array}{c}\text { Distribution } \\
\text { Channel }\end{array}$ &, 348 &, 041 &, 694 & 8,520 &, 000 \\
\hline
\end{tabular}

Based on Table 2 above, it can be concluded that the distribution channel variable with tcount 8,520> from ttable or 8,520> 1,992 then $\mathrm{H} 1$ is accepted, meaning that the distribution channel has an influence on sales volume.

To find out how big the influence is, the Correlation Coefficient and the Coefficient of Determination are tested. For more details, it can be seen in Table 3 below:

Table 3. Summary Model (Correlation Coefficient Test and Determination Coefficient Test) 
The results of data processing in Table 3 show that the correlation coefficient $(R)$ is 0.694 , which means that the Distribution Channel variable has a strong influence on the Sales Volume variable. It is known that the $\mathrm{R}$ square value of 0.482 , or $48.2 \%$, shows that the distribution channel has an influence on sales volume of $48.2 \%$, while the remaining $51.8 \%$ is influenced by other variables not examined by the author. The following is Table 4 , the results of ANOVA data processing

Table 4. ANOVA

\begin{tabular}{|l|l|r|r|r|r|r|}
\hline \multicolumn{2}{|l|}{ Model } & $\begin{array}{c}\text { Sum of } \\
\text { Squares }\end{array}$ & \multicolumn{1}{c|}{ df } & $\begin{array}{c}\text { Mean } \\
\text { Square }\end{array}$ & F & Sig. \\
\hline \multirow{2}{*}{1} & Regression & 756.031 & 1 & 756.031 & 72.592 & $.000^{\mathrm{b}}$ \\
\cline { 2 - 7 } & Residual & 812.356 & 78 & 10.415 & & \\
\cline { 2 - 7 } & Total & 1568.388 & 79 & & & \\
\hline
\end{tabular}

Based on Table 4 above, it is known that the sig value is $0.000<0.05$, so it can be concluded that the distribution channel has a significant effect.

\section{Discussion}

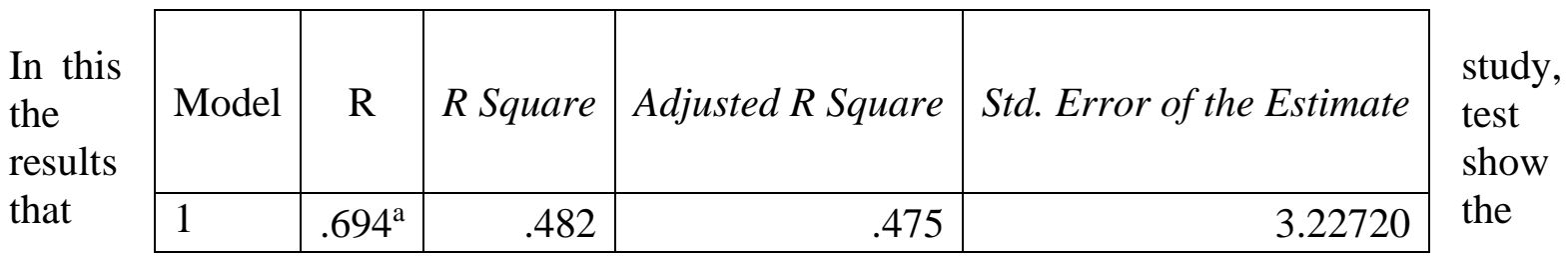

Distribution Channel variable has a significant influence on the Sales Volume variable at PT. Honda Power Products Indonesia. The results of the study are in accordance with the understanding that distribution channels are a route or series of intermediaries in delivering products from producers to consumers (Dhipayana, 2018). This study is also in line with the most recent research on "Between the Accuracy of Distribution Channels and Sales Volume", namely the results of the study show that the accuracy of distribution channels has a significant effect on sales volume. So it can be concluded that the test results in this study are in accordance with previous research and the theory that distribution channels have a significant effect on sales volume at PT. Honda Power Products Indonesia.

The results of this study also show the value of the Correlation Coefficient of 0.694 which means that the Distribution Channel variable has a strong influence on the Sales Volume variable. While the coefficient of determination of 0.482 or $48.2 \%$ indicates that the distribution channel has an influence on sales volume by $48.2 \%$, while the remaining $51.8 \%$ is influenced by other variables not observed in this study. The results of this study are in line with previous research on "The Effect of Distribution Channels on Sales Volume at PT. Sinar 
Kalimantan Berau "(Indriani, 2018), namely the coefficient of determination can explain that the variations in the ups and downs of sales volume of PT Sinar Kalimantan Berau $41 \%$ are influenced by distribution channels, while the other $59 \%$ are influenced by other variables not included in the study. So, it can be concluded that the Distribution Channel variable has an influence on the Sales Volume variable in accordance with previous research.

\section{CONCLUSION}

The conclusion in this study is that there is a positive and significant influence between the X-Distribution Channel variable on the Y-Sales Volume variable at PT. Honda Power Products Indonesia, which is indicated by the linear regression equation $\mathrm{Y}=13,134+$ $0.195 \mathrm{X} 1+\mathrm{e}$. The $\mathrm{t}$ test results show that $\mathrm{t}$ count 8,520>1,992, then the hypothesis $\mathrm{H} 1$ is accepted or the Distribution Channel variable has a significant effect on the Sales Volume variable.

The results also show that the Correlation Coefficient is 0.694 , which means that the Distribution Channel variable has a strong influence on the Sales Volume variable. While the coefficient of determination is 0,482 or $48.2 \%$, indicating that the influence of the Distribution Channel variable on the Sales Volume variable is $48.2 \%$ and the remaining $51.8 \%$ is influenced by other variables not observed in this study.

\section{REFERENCE}

Kadir, Abdul (2003). Introduction to Information System. Yogyakarta: ANDI Kurniawan, Wawan (2008). Laws and regulations. Jakarta: Azka Press.

State Administration Institution, Regional Asset Management Technical Training, Module I: Basics of Regional Asset / Property Management. 2007.

The Republic of Indonesia, Decree of the Minister of Home Affairs No.29 of 2002, Concerning Guidelines for Regional Financial Management, Accountability and Supervision as well as procedures for the Preparation of Regional Revenue and Expenditure Budgets, Implementation of Regional Financial Administration and Compilation of Regional Income Budget Calculations and Belpakidinganja.

Republic of Indonesia, Decree of the Minister of Finance No.1 of 2001, Concerning Guidelines for Capitalizing State Property / Assets in the Government Accounting System.

Republic of Indonesia, Minister of Home Affairs Regulation No. 17 of 2007, Concerning technical guidelines for the management of regional property.

Republic of Indonesia, Minister of Home Affairs Regulation No. 53 of 2011, Concerning the Formation of Regional Legal Products.

Republic of Indonesia, Government Regulation no. 56 of 2005,Concerning the Regional Financial Information System.

Republic of Indonesia, Government Regulation no. 58 of 2005,Concerning Regional Financial Management.

Republic of Indonesia, Government Regulation no. 6 of 2006,Concerning the management of State / Regional Property.

Republic of Indonesia, Government Regulation No.24, 2005.Government Accounting Standards

Republic of Indonesia, Banda Aceh Mayor Regulation No. 63/2010,Regarding Guidelines for Capitalizing Regional Property/Assets in the Accounting Policies of the Banda Aceh City Government. 
Republic of Indonesia, Banda Aceh City Qanun No.1 of 2007,Concerning the Principles of Regional Financial Management.

Republic of Indonesia, Republic of Indonesia Law No.1 of 2004, Regarding the State Treasury.

Republic of Indonesia, Republic of Indonesia Law No.10 of 2004, Concerning the Formation of Legislative Regulations.

Republic of Indonesia, Republic of Indonesia Law No.11 of 2006,Concerning the governance of Aceh.

Republic of Indonesia, Republic of Indonesia Law No. 12 of 2004,Concerning the formation of legislation.

Republic of Indonesia, Republic of Indonesia Law No. 17 of 2003, Concerning State Finance.

Republic of Indonesia, Republic of Indonesia Law No.32 of 2004,Concerning local government.

Republic of Indonesia, Republic of Indonesia Law No.33 of 2004,Concerning the financial balance between the central government and local governments.

Compilation of Regulations concerning State Wealth Inventory, Ministry of Finance of the

Republic of Indonesia, State Financial Accounting Agency, 1995.

http://jdih.bsn.go.id/index.php?option=com_content\&view=article\&id=60:regulasi\&catid=36 :info-hukum\&Itemid=59.

http://manajemenaset08.blogspot.com/2009/01/sistem-informasi-manajemen-aset daerah.html.

http://manajemenaset08.blogspot.com/2009/01/sistem-informasi-manajemen-asetdaerah.html.

http://syukriy.wordpress.com/2009/04/25/optimalisasi-pengelolaan-aset-daerah/. http://www.artikata.com/arti-358461-peraturan.html. 